\title{
Siliceous microfossil succession in the recent history of Green Bay, Lake Michigan
}

\author{
E. F. Stoermer ${ }^{1}$, J. P. Kociolek ${ }^{2}$, C. L. Schelske ${ }^{3}$ \& N. A. Andresen ${ }^{1}$ \\ ${ }^{1}$ Center for Great Lakes \& Aquatic Sciences, University of Michigan, Ann Arbor, MI 48109; USA; \\ ${ }^{2}$ Department of Invertebrate Zoology \& Geology, California Academy of Sciences, Golden Gate Park, \\ San Francisco, CA 94118, USA, ${ }^{3}$ Department of Fisheries and Aquaculture, University of Florida, 7922 \\ NW $71^{\text {st }}$ Street, Gainesville, FL 32606, USA
}

Key words: diatoms, paleolimnology, eutrophication, Great Lakes, Green Bay, Lake Michigan, North America

\begin{abstract}
Quantitative analysis of siliceous microfossils in a ${ }^{210} \mathrm{~Pb}$ dated core from Green Bay of Lake Michigan shows clear evidence of eutrophication, but a different pattern of population succession than observed in the main deposition basins of the Great Lakes. Sediments deposited prior to extensive European settlement (ca A.D. 1850) contain high relative abundance of chrysophyte cysts and benthic diatoms. Quantity and composition of microfossils deposited during the pre-settlement period represented in our core is quite uniform, except for the $30-32 \mathrm{~cm}$ interval which contains elevated microfossil abundance and particularly high levels of attached benthic species. Total microfossil abundance and the proportion of planktonic diatoms begins to increase $c a 1860$ and rises very rapidly beginning $c a 1915$. Maximum abundance occurs in sediments deposited during the 1970's, with a secondary peak in the late 1940's - early 1950's. Increased total abundance is accompanied by increased dominance of taxa tolerant of eutrophic conditions, however indigenous oligotrophic taxa, particularly those which are most abundant during the summer, are not eliminated from the flora, as in the lower Great Lakes. It appears that a combination of silica resupply from high riverine loadings and replacement of indigenous populations by periodic intrusions of Lake Michigan water allow sequential co-existence of species usually exclusively associated with either eutrophic or oligotrophic conditions.
\end{abstract}

\section{Introduction}

Green Bay is a large, semi-enclosed, embayment of Lake Michigan (Fig. 1). It was formed during the Wisconsin glaciation, apparently as the result of differential glacial scour of relatively friable dolomitic shales lying between the more resistant Platteville-Galena dolomite to the west and the Niagara dolomite to the east. The resultant configuration is a long $(190 \mathrm{~km})$, narrow (mean width
$37 \mathrm{~km}$ ), shallow (mean depth $40 \mathrm{~m}$ ) bay with a northeast-southwest median axis. The southern part of the bay is separated from Lake Michigan, except for the Sturgeon Bay Canal, by the Door Peninsula, a region of high local relief formed by exposures of the Niagara dolomite. To the north and east these exposures continue, as several large and numerous smaller islands, to the Garden Peninsula. Thus, although the northern region of Green Bay is partially separated from Lake Mich- 


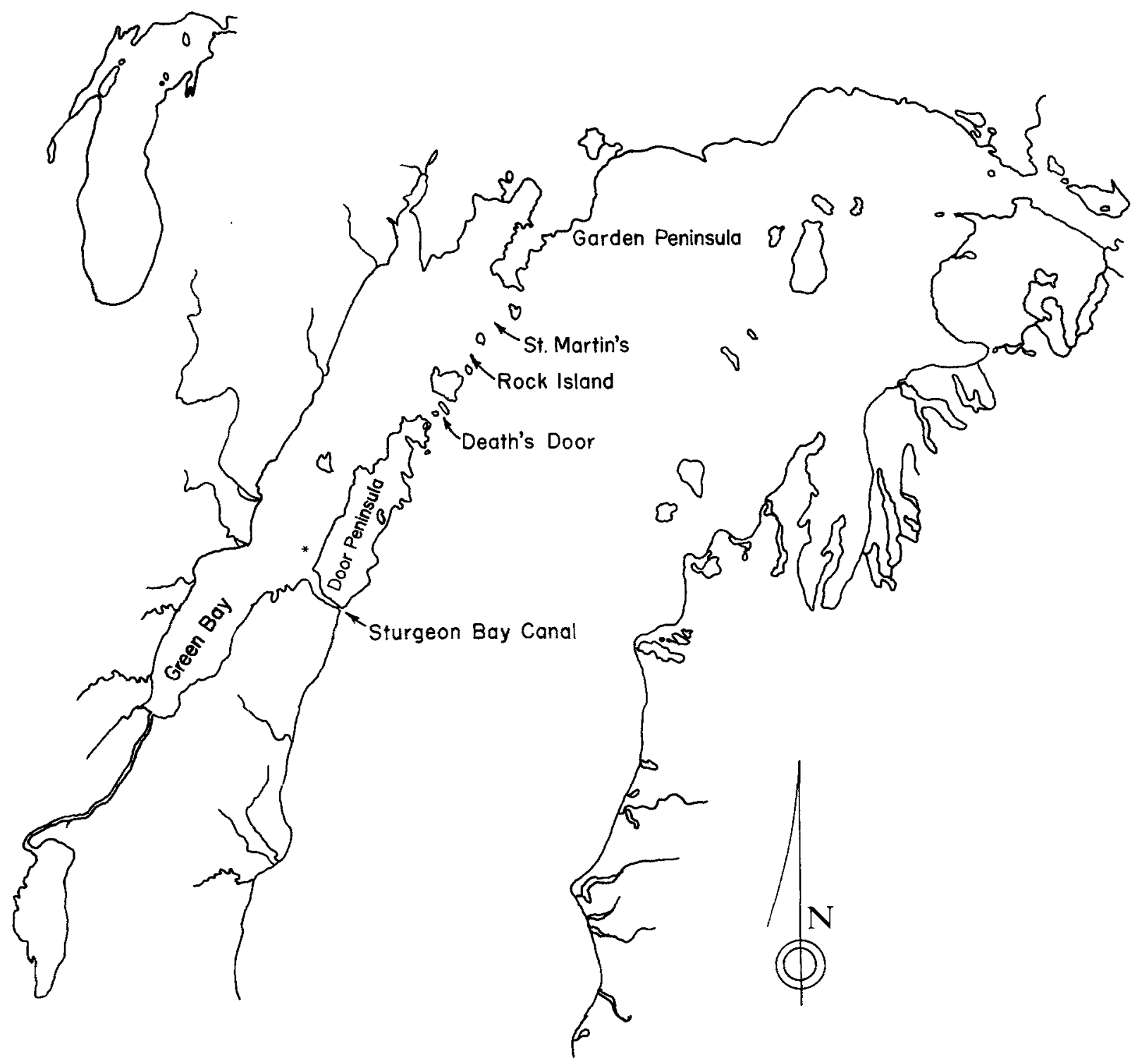

Fig. 1. Outline map of Green Bay, showing coring locality (*).

igan, water is freely exchanged through several passages such as Death's Door, the Rock Island Passage, and the St. Martin's Island Passage. Contrasted to the bedrock exposures which dominate the physiography of the northeastern part of Green Bay, the southwestern border consists of low-relief glacial terrains and glacial lacustrine plains. These trends are reflected in the bay's bathymetry, with greatest depths $(>60 \mathrm{~m})$ occur- ring in the eastern and northern regions and extensive shallows $(<20 \mathrm{~m})$ along the southern and western shores (Moore \& Meyer, 1969). The surface area of the bay is approximately $4200 \mathrm{~km}^{2}$ and its volume is approximately $70 \mathrm{~km}^{3}$. Although these are very minor fractions of the total surface area and volume of Lake Michigan, 0.07 and 0.014 , respectively, Green Bay's drainage is relatively large, constituting more than $33 \%$ of the 
total Lake Michigan drainage basin. Physical factors affecting the distribution of terrestrial loadings are complex (Ahrnsbrak, 1971; Heaps, Mortimer \& Fee, 1982; Miller \& Saylor, 1985). In general, the bay tends to set up two circulation cells, one in the southern and one in the northern region. However, the dispersion of materials is highly subject to stochastic meteorological events, particularly those forcing exchange of water with the main body of Lake Michigan.

Based on the above considerations, Green Bay has likely always been one of the more productive regions of the Great Lakes system. Actual historical data supporting this supposition is minimal, and it is clear that the modern trophic status of Green Bay has been strongly modified by human activities in its watershed (Bertrand et al., 1976). European influence in the region dates to the original explorations of Nicolet in 1634. However, it was not until approximately 200 yrs later that opening of land offices in the area attracted large numbers of western settlers and large scale modification of the Green Bay watershed began. Once initiated, the process occurred rapidly. Deforestation of the watershed began during the 1860 's and 1870's and was essentially complete by 1900 . Intensive agriculture began during the 1890's and has remained important in the region together with paper production and other forms of industry (Bertrand et al., 1976).

For approximately the past 50 years Green Bay has shown progressive evidences of cultural eutrophication, including deoxygenation of bottom waters, reduced transparency, and modification of biological communities (Bertrand et al., 1976). In the case of algal communities, many populations associated with very eutrophic environments are present, however the distribution of particular taxa and community associations is extremely variable spatially and temporally (Holland \& Claflin, 1975; Stoermer \& Stevenson, 1980). It is noteworthy that several diatom species which have been eliminated from the flora of the lower Great Lakes (Stoermer et al., 1985; 1987) are present, and in some cases remain abundant, in Green Bay even though it has undergone severe eutrophication according to most measures.
The objective of the present investigation is to determine the history of eutrophication in Green Bay and to evaluate the factors which distinguish the population responses in this system from those observed in other areas of the Great Lakes system.

\section{Materials and methods}

Material used in this study was derived from a core taken from $31 \mathrm{~m}$ depth at a location (Fig. 1) on the margin of the southern deposition in Green Bay in 1983 (Conley, 1987). The $40 \mathrm{~cm}$ core was taken with a $7.5 \mathrm{~cm}$ diameter Wildco gravity corer. Surface sediments were apparently undisturbed and there were no apparent physical disturbances of lithology in the section. The core was transversely sectioned immediately after retrieval, using a hydraulic extruder. Sections were taken at $0.5 \mathrm{~cm}$ intervals to $10 \mathrm{~cm}$ at $1 \mathrm{~cm}$ intervals between 10 and $20 \mathrm{~cm}$, and at $2.0 \mathrm{~cm}$ intervals to $40 \mathrm{~cm}$. Samples were frozen immediately after sectioning and remained frozen until they were returned to the laboratory. In the laboratory, frozen sediment samples were weighed, freeze dried, then re-weighed for determination of dry weight and porosity. The freeze dried material was then sub-divided for dating, chemical analysis, and microfossil analysis.

The chronology of the core was obtained from non-destructive, direct gamma counting of ${ }^{210} \mathrm{~Pb}$ using an intrinsic Germanium well detector and a 4096 channel multichannel analyzer calibrated at $0.5 \mathrm{kev} / \mathrm{channel}$. The applications and benefits of this method have been discussed by Appleby et al.(1986). Freeze-dried samples were weighed and pressed in $14 \mathrm{~mm}$ diameter plastic vials to a nominal depth of $30 \mathrm{~mm}$ and then sealed with epoxy resin. Samples were then stored for at least two weeks to allow for ingrowth of supported ${ }^{210} \mathrm{~Pb}$ and ${ }^{214} \mathrm{Bi}$ from the decay of ${ }^{222} \mathrm{Rn}$. Activities of the $46.52 \mathrm{kev}$ and $609.1 \mathrm{kev}$ gamma energies of ${ }^{210} \mathrm{~Pb}$ and ${ }^{214} \mathrm{Bi}$, respectively, were measured. The activity measured as ${ }^{210} \mathrm{~Pb}$ represented total ${ }^{210} \mathrm{~Pb}$ in the sample. Excess ${ }^{210} \mathrm{~Pb}$ was obtained by subtracting the activity of ${ }^{214} \mathrm{Bi}$ from 
that of total ${ }^{210} \mathrm{~Pb}$. A factor to correct for changes in efficiency with height was used to calculate activities for each sample. Ages were calculated with a CRS model.

Biogenic silica concentrations were determined using methods described by Conley et al. (1986) and have been reported by Conley (1987).

Methods detailed by Stoermer et al. (1985a) were used for siliceous microfossil preparation enumeration, and data analysis.

\section{Results}

Results of excess ${ }^{210} \mathrm{~Pb}$ calculations showed a departure from the ideal logarithmic decrease with cumulative weight (or sediment depth) that would be expected if the mass sedimentation rate were constant. The upper $2.5 \mathrm{~cm}$ of the core had relatively constant activity, indicating a mixed layer. A zone of relatively high sedimentation was found from 3 to $11 \mathrm{~cm}$. Mass sedimentation generally increased in this zone from $27 \mathrm{mg} \mathrm{cm}^{-2} \mathrm{yr}^{-1}$ at $11 \mathrm{~cm}$ to $50 \mathrm{mg} \mathrm{cm}^{-2} \mathrm{yr}^{-1}$ at $3 \mathrm{~cm}$. Mass sedimentation rates were much lower from $12 \mathrm{~cm}$ to $24 \mathrm{~cm}$ and, with one exception, ranged from 18 to $25 \mathrm{mg} \mathrm{cm}^{-2} \mathrm{yr}^{-1}$. Below $24 \mathrm{~cm}$, levels of unsupported ${ }^{210} \mathrm{~Pb}$ were too low for reliable estimates of sediment ages and sedimentation rates. Much of the increase in apparent sedimentation rate above $11 \mathrm{~cm}$ can be attributed to increased deposition of biogenic silica. Concentrations of biogenic silica above $12 \mathrm{~cm}$ ranged from 15 to 20 percent of sediment dry mass, whereas concentrations below $15 \mathrm{~cm}$ were generally less than 3 percent. Based on data from other cores from eutrophied areas of the Great Lakes (Schelske et al., 1988), we would assume that the rate of organic carbon accumulation also increased upcore and contributed to higher mass sedimentation rates.

A total of 242 morphologically identifiable entities were noted during the study. Of these 229 were diatoms. Chrysophytes were represented by 11 cyst and 2 scale types. Many of the entities noted were present in such low numbers that statistically reliable estimates of their abundance were not obtained with our analysis methods. These taxa will not be discussed further but complete data listings can be obtained from the senior author.

Total abundance of benthic and planktonic diatoms is shown in Fig. 2. For convenience in discussion, a depth-date zonation developed on the basis of cluster analysis (Euclidean distance measure, average clustering method) of the relative abundance of populations constituting more than $1 \%$ of the assemblage in at least 5 samples (Fig. 3) is also given in Fig. 2 and in subsequent plots of microfossil abundance. The relative abundance

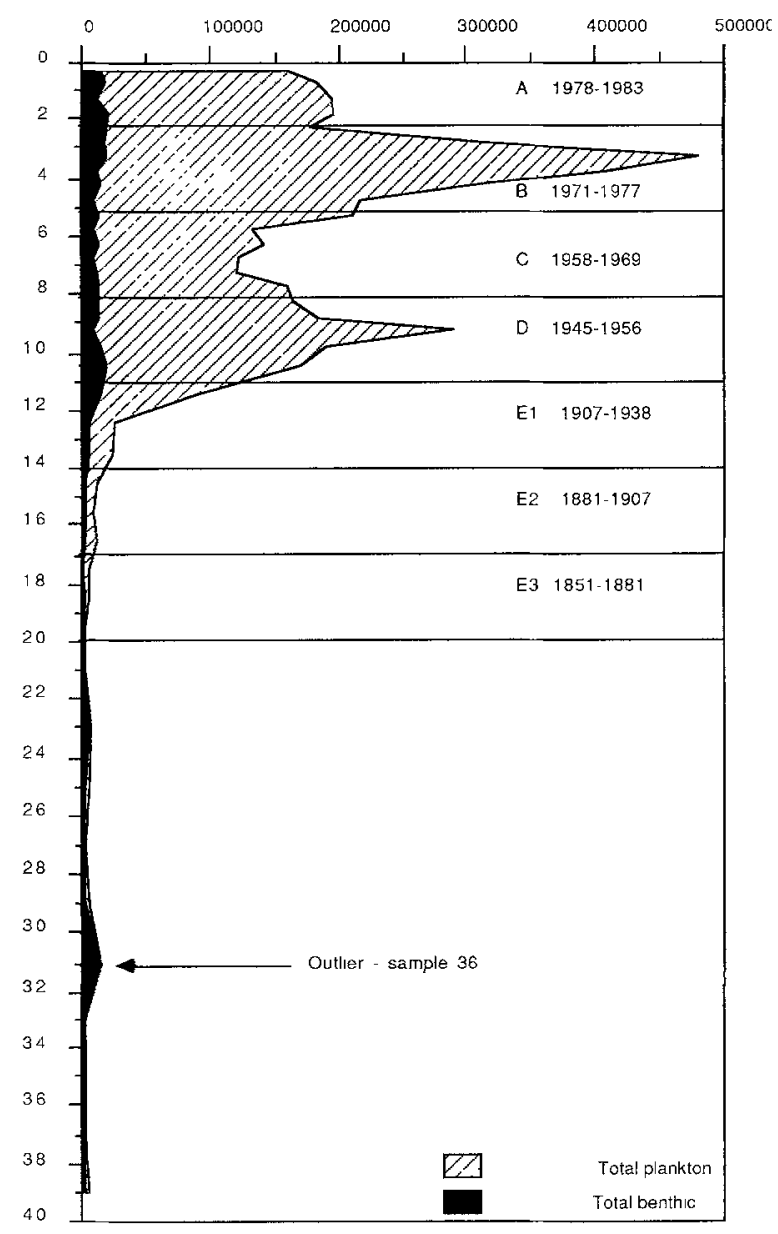

Fig. 2. Abundance (values $\mathrm{mg}^{-1}$ ) of planktonic and benthic diatoms relative to depth $(\mathrm{cm})$ in core. Zonation indicated by horizontal rules is based on cluster analysis. Dating of intervals is based on ${ }^{210} \mathrm{~Pb}$. 


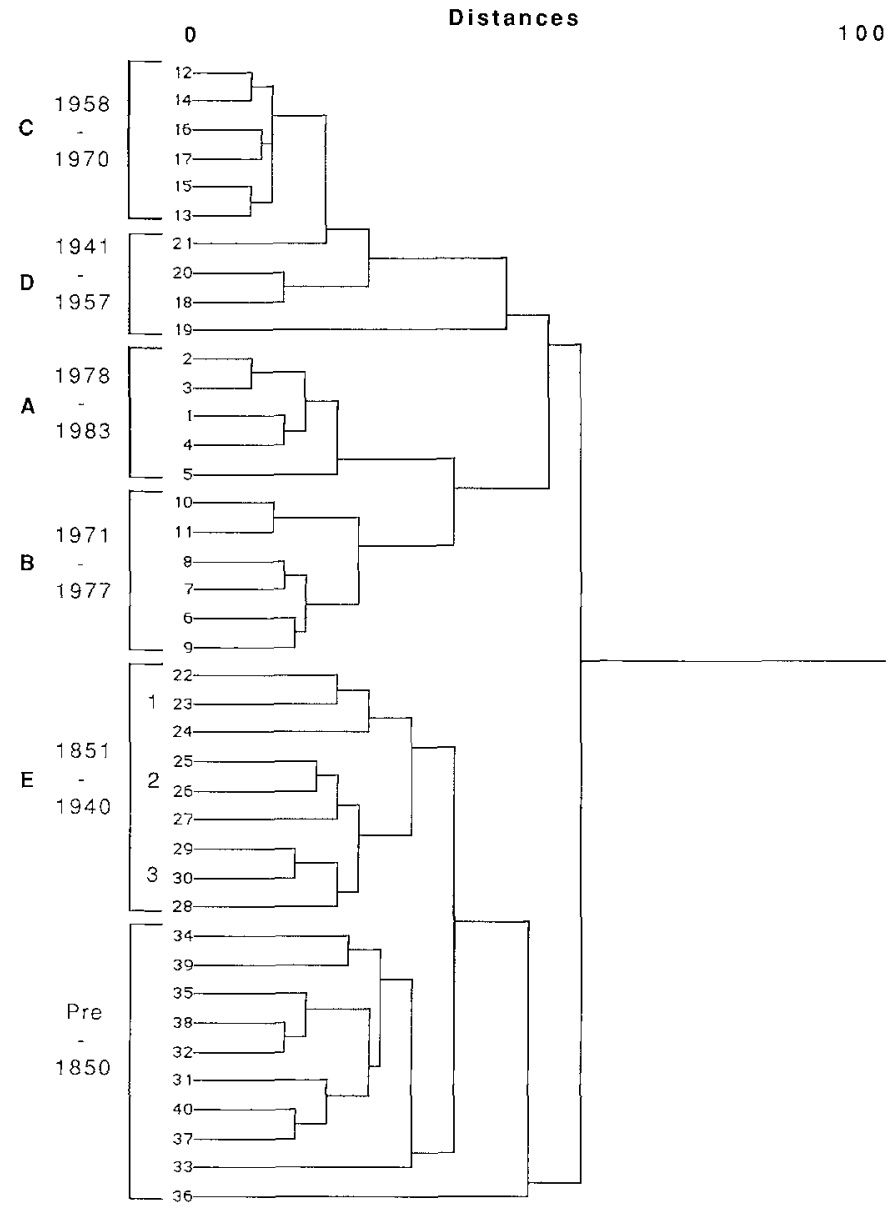

Fig. 3. Cluster dendrogram (Euclidian distance, average clustering method) based on relative frequency of most abundant taxa. Dates associated with inferred sample groupings are based on ${ }^{210} \mathrm{~Pb}$.

of most abundant diatom genera and chrysophycean cysts is shown in Figs. $4 \& 5$. Plots of the absolute abundance of major diatom genera and numerically important species are shown in Figs. 6-14.

With the conspicuous exception of sample 36, diatom abundance (Fig. 2) is low and relatively uniform in samples from below $20 \mathrm{~cm}$ in the core. Abundance, particularly of planktonic species, begins to increase in zone E3, undergoes slight further increase in zone E2, then begins marked increase in zone E1, particularly the upper samples. Following this initial increase, there are no- table abundance peaks in zones $\mathrm{D}$ and $\mathrm{B}$. Most of the increase noted is attributable to planktonic species. Benthic populations undergo some increase in abundance, particularly in zone E1, but remain a relatively minor fraction of the total assemblage in samples above $17 \mathrm{~cm}$.

The relative abundance (Figs $4 \& 5$ ) of chrysophycean cysts and predominantly benthic diatom genera generally declines in zone $\mathrm{E}$, particularly between zone E3 and zone E2, and these populations never regain their former relative importance. They are minor constituents of the flora in zones A-D. Conversely, predominantly plankton diatom genera increase in zone $\mathrm{E}$ and remain dominant in the upper sections of the core. There are, however, differences between genera in the pattern of increase and decline. Cyclotella (Fig. 4) is most abundant in zone $\mathrm{E} 1$ and declines in relative importance thereafter. Fragilaria (Fig. 4) has relative abundance peaks in both the upper and lower sections of the core, but this is somewhat deceptive, since the lower peaks consist mostly of benthic species, such as Fragilaria (Staurosirella) pinnata, while the upper peaks consist mostly of planktonic (Fragilaria crotonensis) and tychoplanktonic ( $F$. capucina) species. Species of Melosira (Aulacoseira) reach maximum relative abundance in zone $\mathrm{D}$ and decline strongly in zone A, whereas Stephanodiscus species constitute particularly large proportions of the total assemblage in zones $\mathrm{E} 1$ and $\mathrm{A}$ and Tabellaria species are particularly abundant in zones E3 and A (Fig. 5). It should be noted that sample 36 contains particularly large proportions of some typically sessile (Achnanthes and Cocconeis) and vagile ( $\mathrm{Na}$ vicula) benthic genera.

The absolute abundance of Cyclotella (Fig. 6) begins to increase in zone $\mathrm{E} 3$, reaches near maximum abundance at the boundary between zones E1 and D, then remains fairly stable except for a peak in zone B. Individual constituent populations behave somewhat differently. Cyclotella comta, the most common species in Green Bay, is most abundant in samples around the boundary between zones $\mathrm{E} 1$ and $\mathrm{D}$. It then declines through zone $\mathbf{B}$, with a slight increase in zone A. Other species show a more consistently increas- 


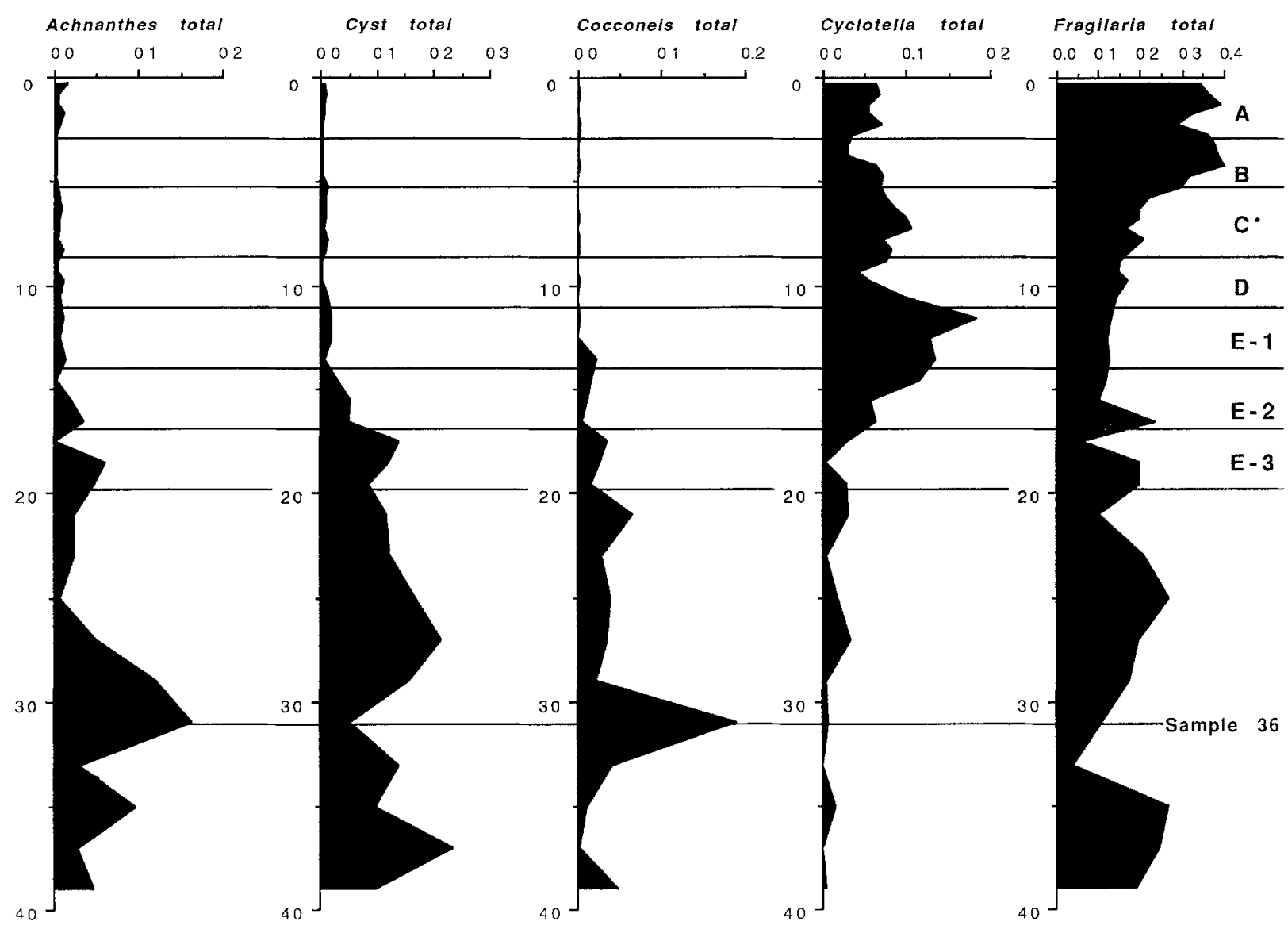

Fig. 4. Relative frequency of diatom genera and chrysophyte cysts relative to depth in core. Zonation indicated by horizontal rules is inferred from cluster analysis.

ing trend, which continues to the surface in C. michiganiana but terminates in zone $\mathrm{B}$ in $C$. kuetzingiana and $C$. operculata. Several Cyclotella species (Fig. 7) which are, or were, numerically important in other areas of the Great Lakes (Stoermer et al., 1985a, b; 1987; 1990, Wolin et al., 1988) are less abundant in Green Bay and their pattern of occurrence is erratic. Among these, C. comensis is most abundant in the bottom samples of zone A,C. ocellata increases through zone $C$, then declines and $C$. stelligera has a single strong abundance peak in zone $B$.

An unknown species of Cyclostephanos (Fig. 7) first occurs in zone $\mathrm{C}$, becomes abundant in zone $\mathrm{B}$, then continues at reduced abundance through zone A.
Fragilaria capucina, a tychoplanktonic species particularly associated with eutrophication in the Great Lakes (Hohn, 1969; Stoermer, 1978) is the most abundant species of the genus, particularly in the upper sections of the core (Fig. 8). It is most abundant in zone $\mathrm{B}$, with minor peaks in zones A and D. Fragilaria crotonensis, a more eurytopic planktonic species follows the same general pattern, while the other important euplanktonic species, $F$. intermedia var. fallax is most abundant in the upper part of the core, particularly zone A. Primarily benthic taxa, such as $F$. (Staurosirella) pinnata are much less abundant, and their abundance is more uniform throughout the core.

The most abundant Melosira (Aulacoseira) spe- 


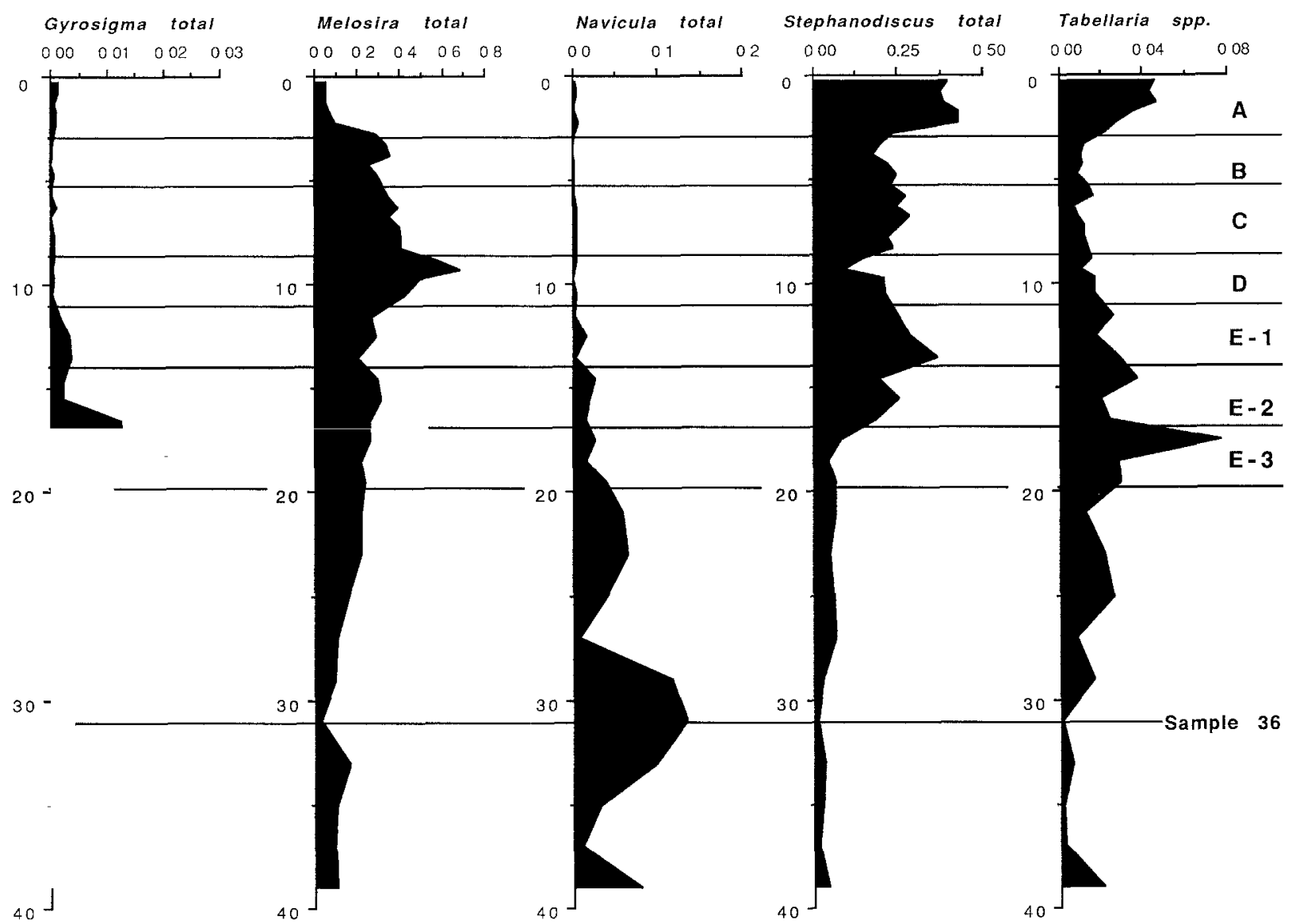

Fig. 5. Relative frequency of diatom genera relative to depth in core. Zonation indicated by horizontal rules is inferred from cluster analysis.

cies reach maxima in zones B and D (Fig. 9). Of these, $M$. granulata is a summer blooming form (Stoermer \& Ladewski, 1976). Within the Great Lakes, its distribution is largely limited to nearshore water and areas shallow enough to be windmixed during the summer (Stoermer, 1978). Holland (1968) noted its abundance in southern Green Bay. Among the more generally distributed Melosira species which bloom during cold-season mixing, $M$. italica subsp. subarctica has the same general pattern of occurrence as $M$. granulata, although it reaches maximum abundance in zone $\mathrm{D}$, rather than zone $\mathrm{B}$, while $M$. islandica becomes most abundant in zone D then declines, particularly in zone A. Melosira undulata, which is rare in the modern flora of the Great Lakes, is present in low numbers throughout the lower section of the core but declines in zone E2 and it was not found in samples above the lower part of zone C. This species was also noted in sediments from the Bay of Quinte (Stoermer et al., 1985c) but in smaller numbers.

Species of Stephanodiscus (Figs. 10 \& 11) generally begin to increase in zone $E$ and reach maximum abundance in zone B or the bottom of zone A. Exceptions are $S$. binderanus and $S$. binderanus var. oestrupi which first occur in zones $\mathrm{D}$ and C, respectively, S. hantzschii which has bimodal peaks in zones $\mathrm{D}$ and $\mathrm{E}$, and $S$. minutus, which is only abundant in samples from zones E1-B. Most species of Stephanodiscus present are tolerant of varying degrees of eutrophication. Both 


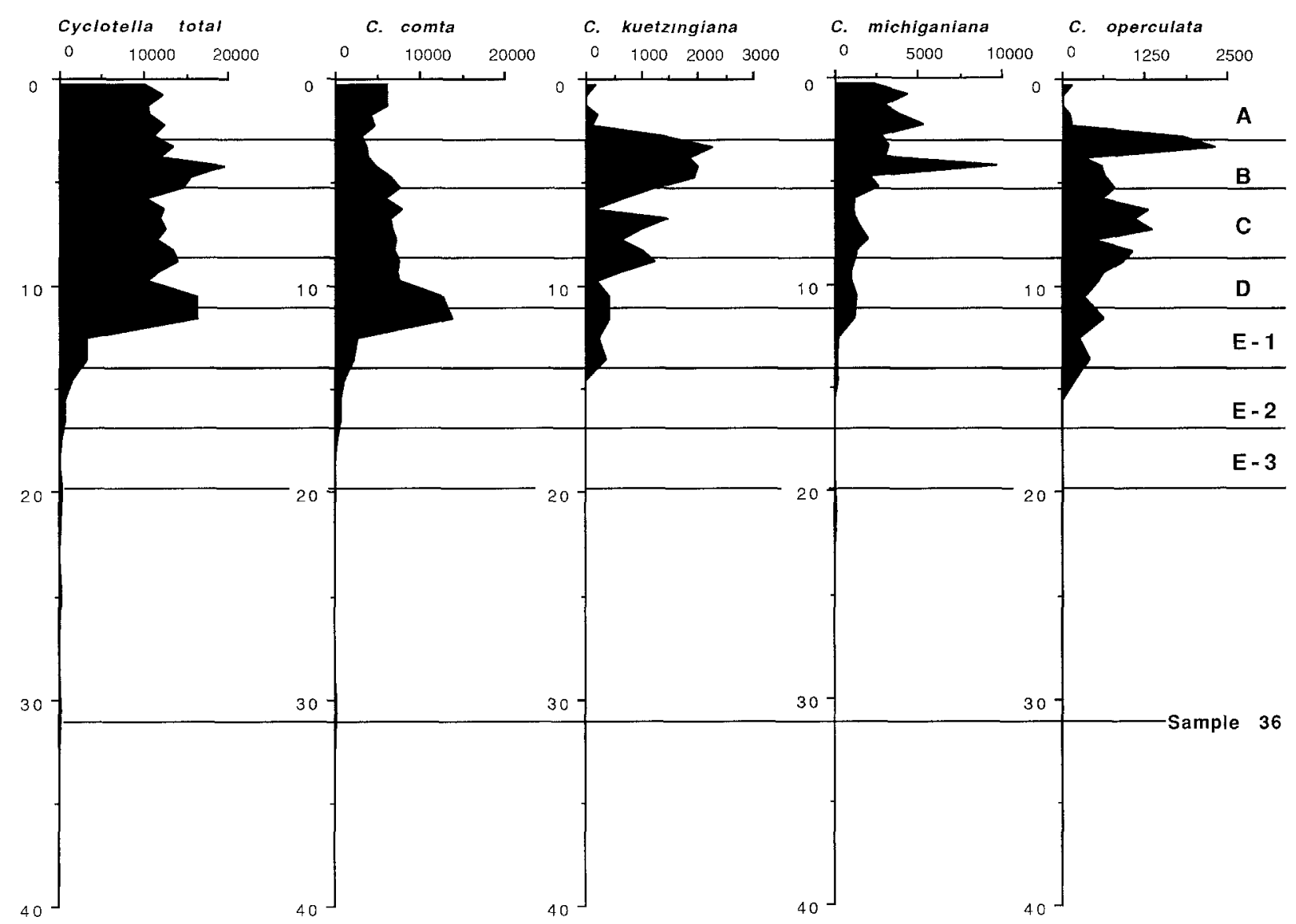

Fig. 6. Abundance (valves $\mathrm{mg}^{-1}$ ) of Cyclotella spp. relative to depth in core. Zonation indicated by horizontal rules is inferred from cluster analysis.

$S$. binderanus and $S$. binderanus var. oestrupi are apparent introductions to the Great Lakes (Brunel, 1956; Stoermer et al., 1979) which occur in disturbed areas, particularly during thermal bar conditions (Stoermer, 1968; Lorifice \& Munawar, 1974). Both $S$. alpinus and $S$. niagarae are widely distributed in the Great Lakes and both have significant variations in morphology, apparently in response to trophic conditions (Theriot \& Stoermer, 1984; Theriot et al., 1988). Both have remained abundant in the lower Great Lakes, although $S$. niagarae may no longer be able to complete sexual reproduction in Lake Ontario (Stoermer et al., 1989). They, together with a species of uncertain taxonomic affinities, here designated as Stephanodiscus sp. \# 10, begin to increase around the boundary between zone E1 and E2 and reach maximum abundance in zone A. Although the general distribution of $S$. parvus is poorly known (Stoermer \& Håkansson, 1984), within the Great Lakes it has become particularly abundant in the Bay of Quinte and Lake Erie (Stoermer et al., 1985c; 1987). The apparent exception to Stephanodiscus species tolerance of eutrophication is $S$. transilvanicus. It is the most abundant species of the genus in samples from zone E3 and below, and is one of few species which are virtually absent from surficial sediments. $A$ similar increase and decline was noted in Lake Ontario (Stoermer et al., 1985a).

Several minor species (Fig. 12) first become abundant in zone E. Asterionella formosa and 


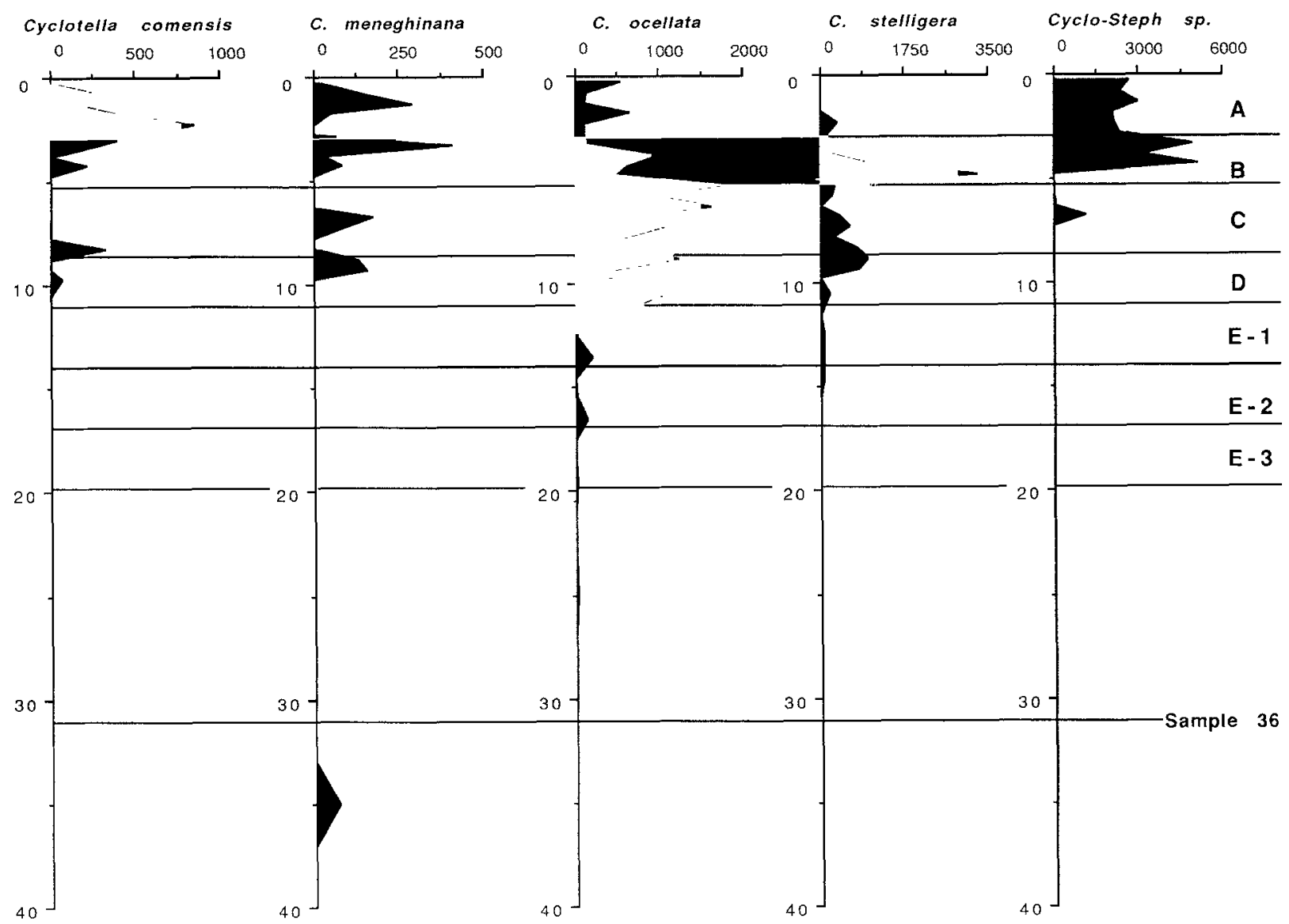

Fig. 7. Abundance (valves $\mathrm{mg}^{-1}$ ) of Cyclotella and Cyclostephanos spp. relative to depth in core. Zonation indicated by horizontal rules is inferred from cluster analysis.

Diatoma tenue var. elongatum increase in zone E1. Increase in Synedra spp. and Tabellaria spp. begins somewhat earlier. Surirella spp., most of which have epipelic growth habit but apparently are entrained in the plankton and become important in Lake Ontario and Lake Erie sediment assemblages (Stoermer et al., 1985a; 1987), become consistently abundant in zone E1 and increase slightly in more recent sediments.

A number of pennate genera which are usually rare in sediment assemblages from deep basins are surprisingly well represented in Green Bay (Figs. 13 \& 14). Species of Nitzschia first increase in zone $\mathrm{E} 1$, then become even more abundant in zones $\mathrm{A}$ and $\mathrm{B}$. The first rise in abundance is due mainly to increased numbers of $N$. dissipata, a species common in plankton collections from the Great Lakes. The second increase is due to increased abundance of several species usually found in epipelic communities and $N$. confinis which commonly grows in the matrix surrounding colonial cyanophytes. Genera with normally attached growth habit, such as Achnanthes, Amphora, Cocconeis, Cymbella, and Gomphonema reach maximum, or near maximum abundance in sample 36, then increase again in samples from zones A-D, particularly in zone A. Navicula, a genus with mostly vagile benthic species shows the same general pattern. In this case, the large peak in sample 36 is formed by exceptional abundance of $N$. radiosa var. tenella. Smaller peaks in the upper section of the core are formed by smaller 


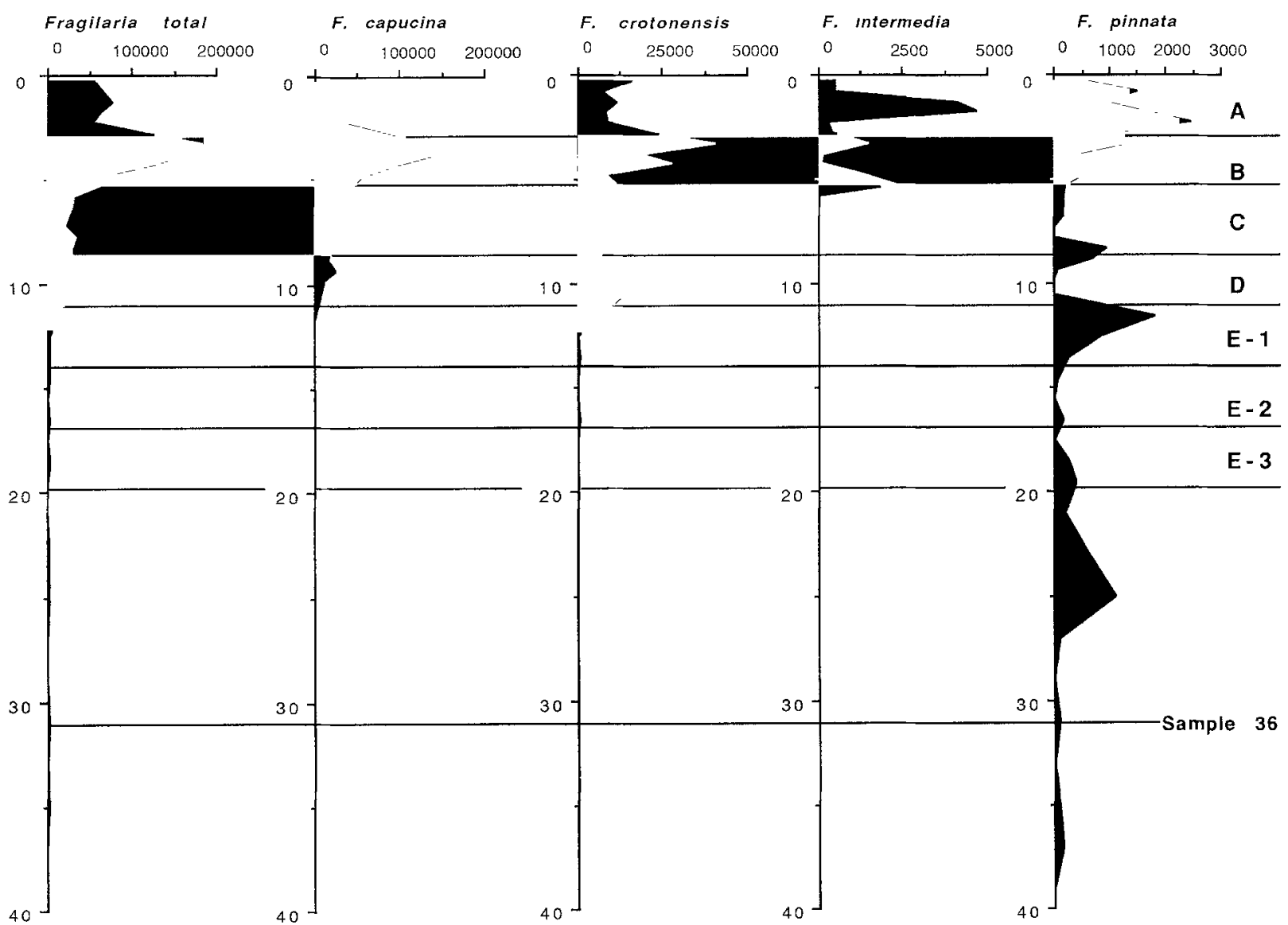

Fig. 8. Abundance (valves $\mathrm{mg}^{-1}$ ) of Fragilaria spp. relative to depth in core. Zonation indicated by horizontal rules is inferred from cluster analysis.

increases in a variety of species. Other mostly epipelic genera show different responses. Species of Gyrosigma generally increase from the bottom to the top of the core. Species of Entomoneis are more abundant in zones A-D than in lower levels of the core. One of the more unusual aspects of plankton communities in Green Bay is the exceptional abundance of Amphipleura pellucida (Holland \& Claflin, 1975; Stoermer \& Stevenson, 1980). This is also the case in our sediment samples, particularly in zone B.

\section{Discussion}

It seems reasonably clear that eutrophication is the major factor driving the succession of sili- ceous microfossils observed in our samples. Increase in total diatom abundance, independently confirmed by increased biogenic silica levels (Conley, 1987) which follow the same trends as our diatom enumeration data, progressive addition of taxa reported to be tolerant of eutrophic conditions, and reduction or elimination of some species associated with oligotrophic conditions all are consistent with this conclusion. The overall timing of changes observed is also consistent with the known history of western settlement and modification of the Green Bay drainage basin (Bertrand et al., 1976). Our data also indicate that algal communities which produce siliceous microfossils were relatively stable over a long period of time prior to western settlement. Proceeding from this basic conclusion, there are, however, a 


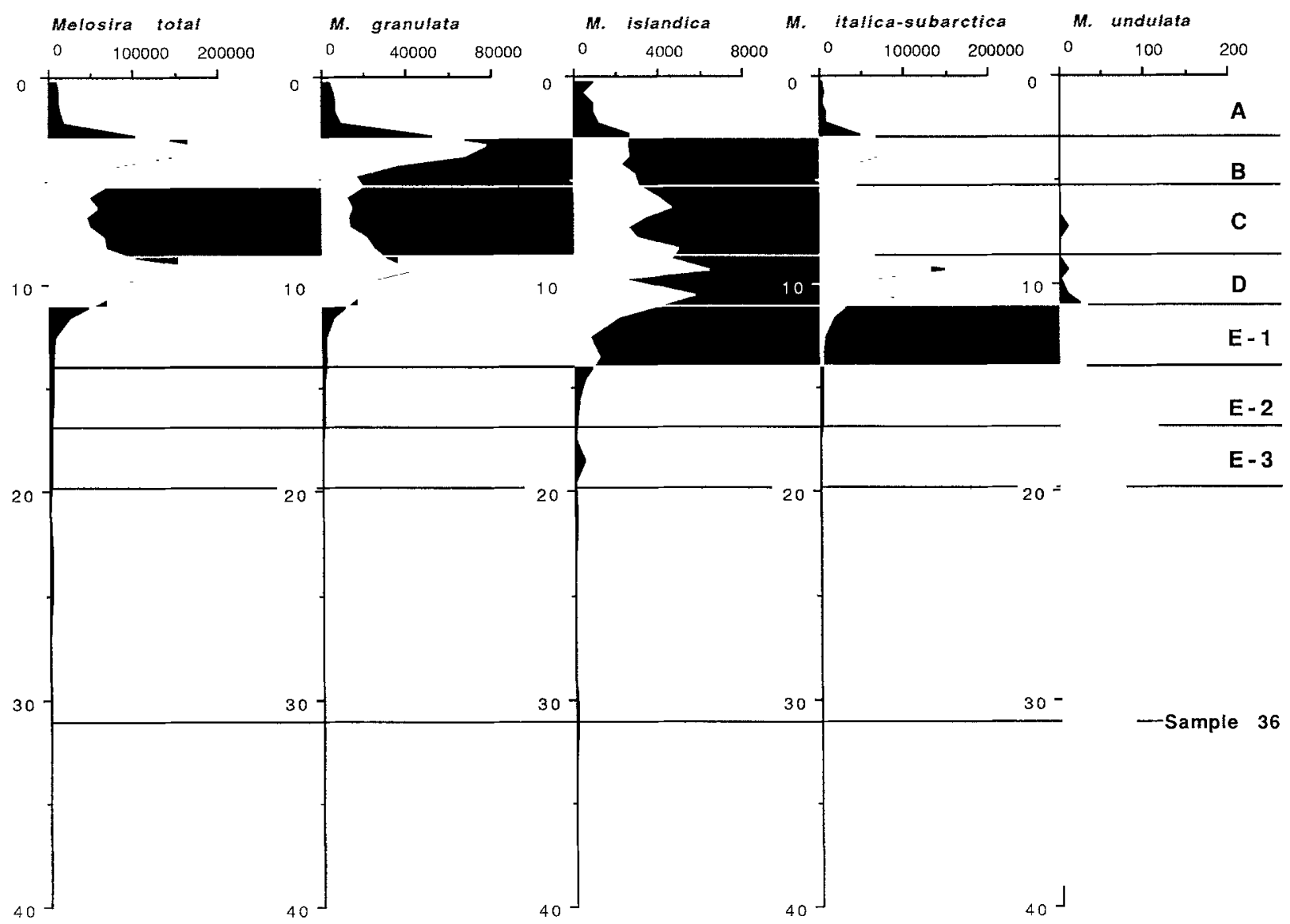

Fig. 9. Abundance (valves $\mathrm{mg}^{-1}$ ) of Melosira spp. relative to depth in core. Zonation indicated by horizontal rules is inferred from cluster analysis.

number of features which distinguish the successional pattern in Green Bay from those observed in other areas of the Great Lakes and most smaller lakes.

The first is the exceptionally high abundance of species normally associated with benthic environments in pre-settlement samples. Although it is generally true that populations derived from benthic habitats are relatively more abundant in pre-settlement samples from cores taken in the deep sedimentation basins of the Great Lakes (Stoermer et al., 1985a; 1987; 1990), even most oligotrophic regions (Stoermer et al., 1985b; Wolin et al., 1988), relative abundance of benthic populations comparable to those found in Green Bay were only observed in pre-settlement sam- ples from the Bay of Quinte (Stoermer et al., 1985c). It thus appears that the benthic contribution to production during the pre-settlement era was even more important in large bays than in open areas of the Great Lakes.

It should also be noted that some populations normally associated with benthic environments are uncommonly abundant in both pre-settlement and post-settlement samples from Green Bay. Amphipleura pellucida (Fig. 13) is consistently present in samples from the upper portion of our core and is particularly abundant in zone B. Although this species is rarely present in more than trace quantities from either modern plankton collections or deep basin sediment samples from most habitats, Holland \& Claflin (1975) and Sto- 


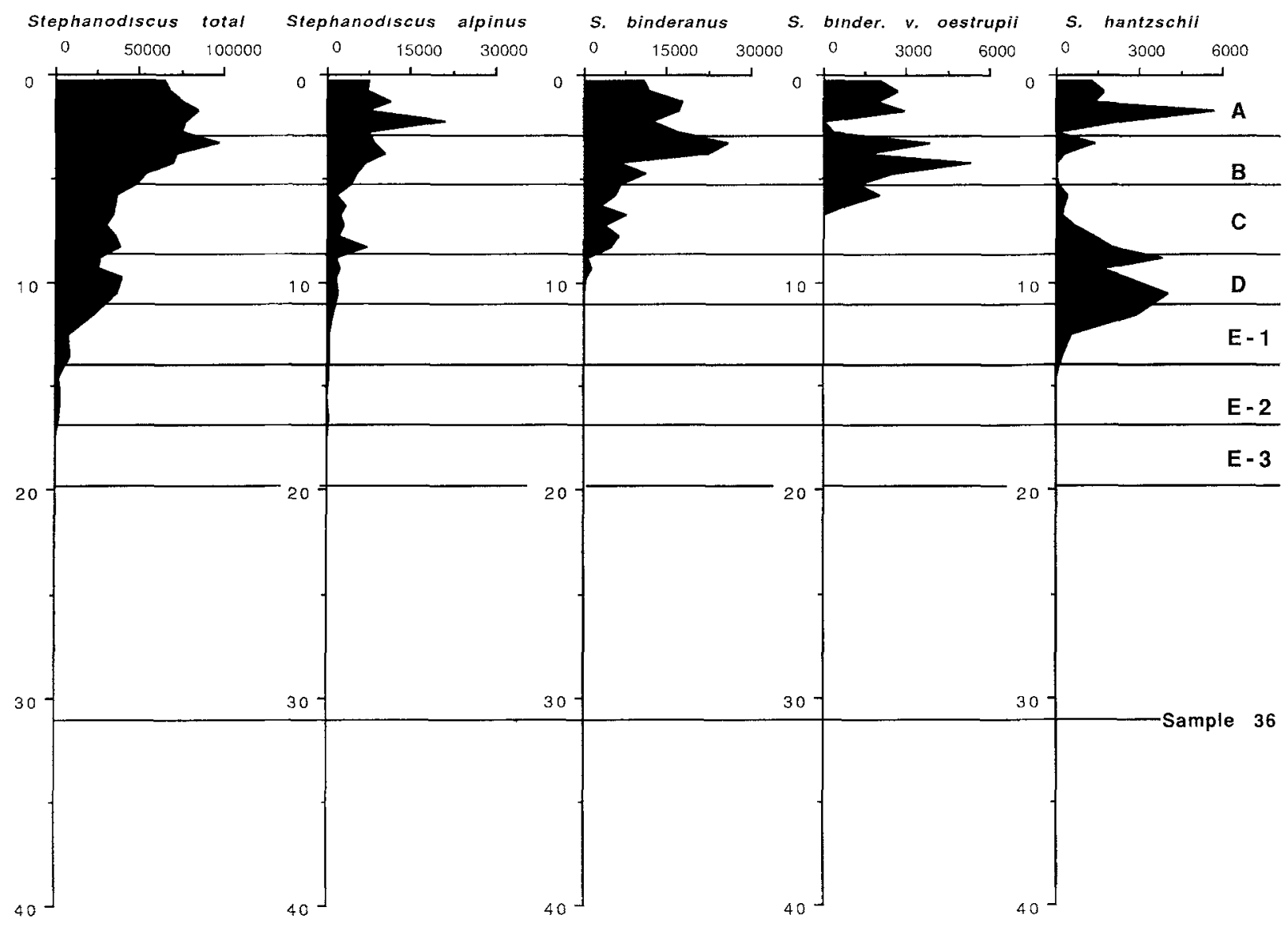

Fig. 10. Abundance (valves $\mathrm{mg}^{-1}$ ) of Stephanodiscus spp. relative to depth in core. Zonation indicated by horizontal rules is inferred from cluster analysis.

ermer \& Stevenson (1980) noted it in modern plankton samples from Green Bay. Melosira undulata (Fig. 9), is consistently present in presettlement and early post-settlement samples. Although occasional specimens of this species have been found in modern benthic collections from the upper Great Lakes, it has only been noted in abundance in a sedimentary sequence from the Bay of Quinte (Stoermer et al., 1985c).

There is one particular sample in the presettlement sequence that bears further comment. Sample 36 is a strong outlier to the major cluster that joins pre-settlement and early post-settlement samples (Fig. 3). This sample contains the highest total abundance of microfossils of any deposited in the pre-settlement era and its atypically rich in benthic diatoms, particularly taxa usually found in periphyton communities, such as Achnanthes, Amphora, Cocconeis, Cymbella, and Gomphonema (Figs. 4, 13 \& 14). A single sample with atypical abundance of benthic species, in this case mostly Fragilaria, was also noted in the pre-settlement sequence from northern Lake Michigan (Stoermer et al., 1990). Although dates extrapolated from ${ }^{210} \mathrm{~Pb}$ are not the same, they are plausibly within large range of possible errors associated with attempting to age older sediments with ${ }^{210} \mathrm{~Pb}$ (Binford, 1990). Thus, although it is not clear that these two highly atypical samples are causally, or even temporally, related, the intruiging possibility remains that the Lake Michigan basin was subjected to some major perturbation prior to western settlement.

Although Green Bay is a much modified sys- 


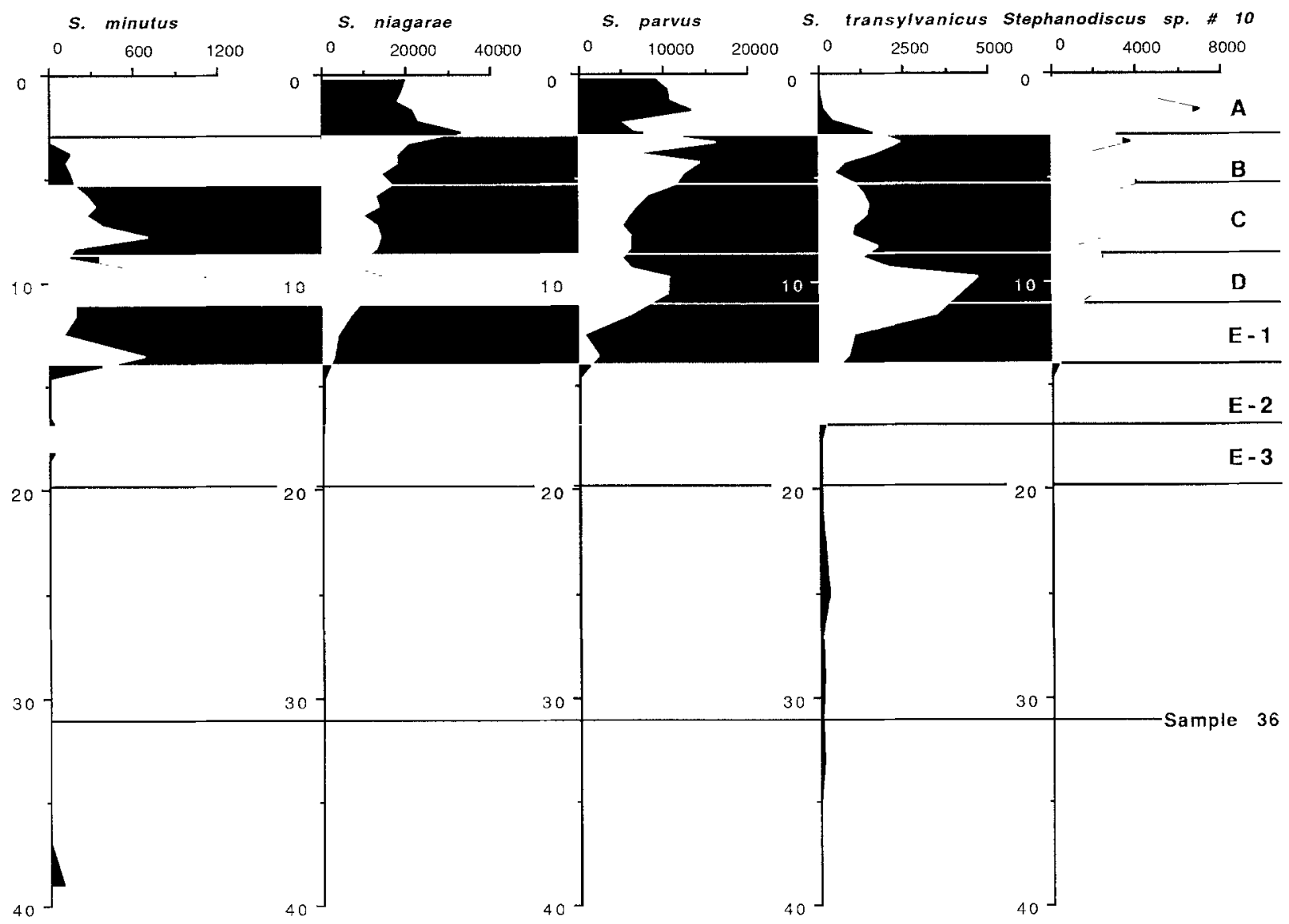

Fig. 11. Abundance (valves $\mathrm{mg}^{-1}$ ) of Stephanodiscus spp. relative to depth in core. Zonation indicated by horizontal rules is inferred from cluster analysis.

tem (Bertrand et al., 1976) and our study shows clear evidence of eutrophication, the timing and degree of change appear to be substantially different than sequences observed in the lower Great Lakes and the Bay of Quinte. The large pulse of siliceous microfossil accumulation associated with western settlement in Lake Ontario (Stoermer et al., 1985a) does not occur in Green Bay. Instead, a gradual increase in siliceous microfossil concentration in sediments begins in the late 1800 's and does not accelerate rapidly until about 1915. Also, the complete, or near complete, suppression of populations associated with oligotrophic conditions observed in Lake Ontario (Stoermer et al., 1985a), the Bay of Quinte (Stoermer etal., 1985c) and Lake Erie (Stoermer et al., 1987) is not observed in Green Bay. In the lower lakes the accumulation of chrysophyte cysts, many species of Cyclotella and certain other populations, such as Stephanodiscus transilvanicus, is enhanced in the immediate postsettlement era but depressed and reduced to near zero in later parts of the record. In Green Bay, the abundance of chrysophyte cysts (Fig. 4) is depressed in zone E2 and remains at low levels throughout more recent levels of the core. The abundance of Cyclotella species peaks in zone $\mathrm{E} 1$ (Fig. 4). Although some populations (C. kuetzingiana, C. operculata; Fig. 6) have much reduced abundance in zone $\mathrm{A}$, most important populations remain present in the flora and there is no marked reduction in abundance of the genus 


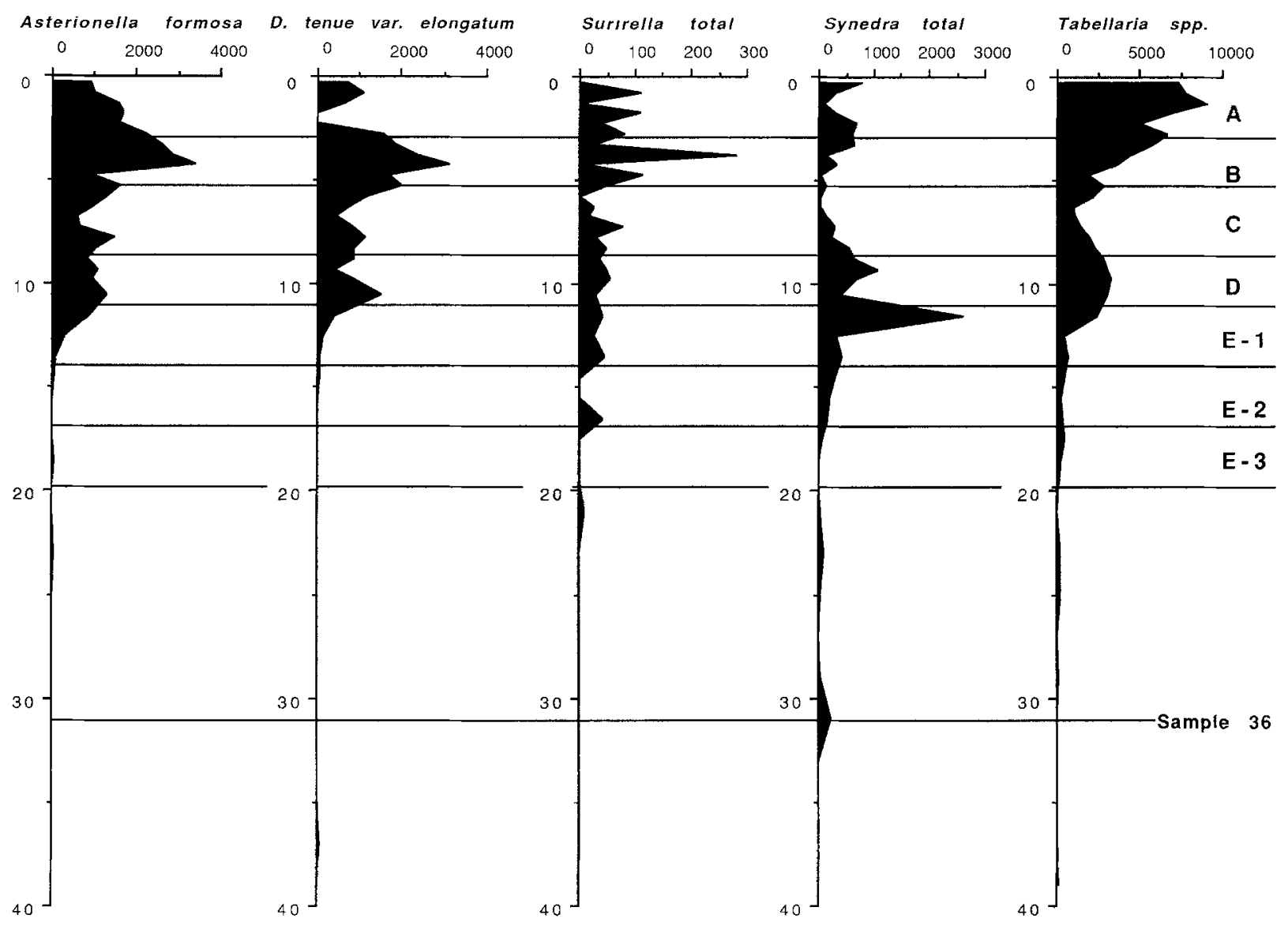

Fig. 12. Abundance (valves $\mathrm{mg}^{-1}$ ) of Asterionella, Diatoma, Surirella, Synedra and Tabellaria spp. relative to depth in core. Zonation indicated by horizontal rules is inferred from cluster analysis.

above zone E1. It thus appears paradoxical that many oligotrophic indicator species remain important elements of the Green Bay flora even though the bay has been significantly eutrophied according to other criteria, such as average phytoplankton abundance (Stoermer \& Stevenson, 1980).

We believe that the explanation of this apparent paradox lies in the morphometric and loading characteristics of Green Bay. Because the northern section of the bay has expansive direct connections to Lake Michigan, nutrient loadings may be rapidly diluted, depending upon local metereological conditions. Previous studies of the modern phytoplankton flora have shown large regional differences in community composition (Holland
\& Claflin, 1975) at any particular time and similarly large regional differences over time (Stoermer \& Stevenson, 1980). It is not surprising that some integration of this spatial heterogeneity should be found in the sedimentary sequence. It should also be noted that although our coring locality is in the southern part of the bay, it is on the boundary of the northern circulation cell (Bertrand et al., 1976). It is thus possible that the sequence recorded is in our core is more representative of conditions in the northern section of Green Bay. This possibility is not supported by the limited evidence available from studies of regional deposition differences in the Great Lakes system. In their study of diatom distribution in Lake Superior sediments, Thayer et al. (1983) found no dis- 


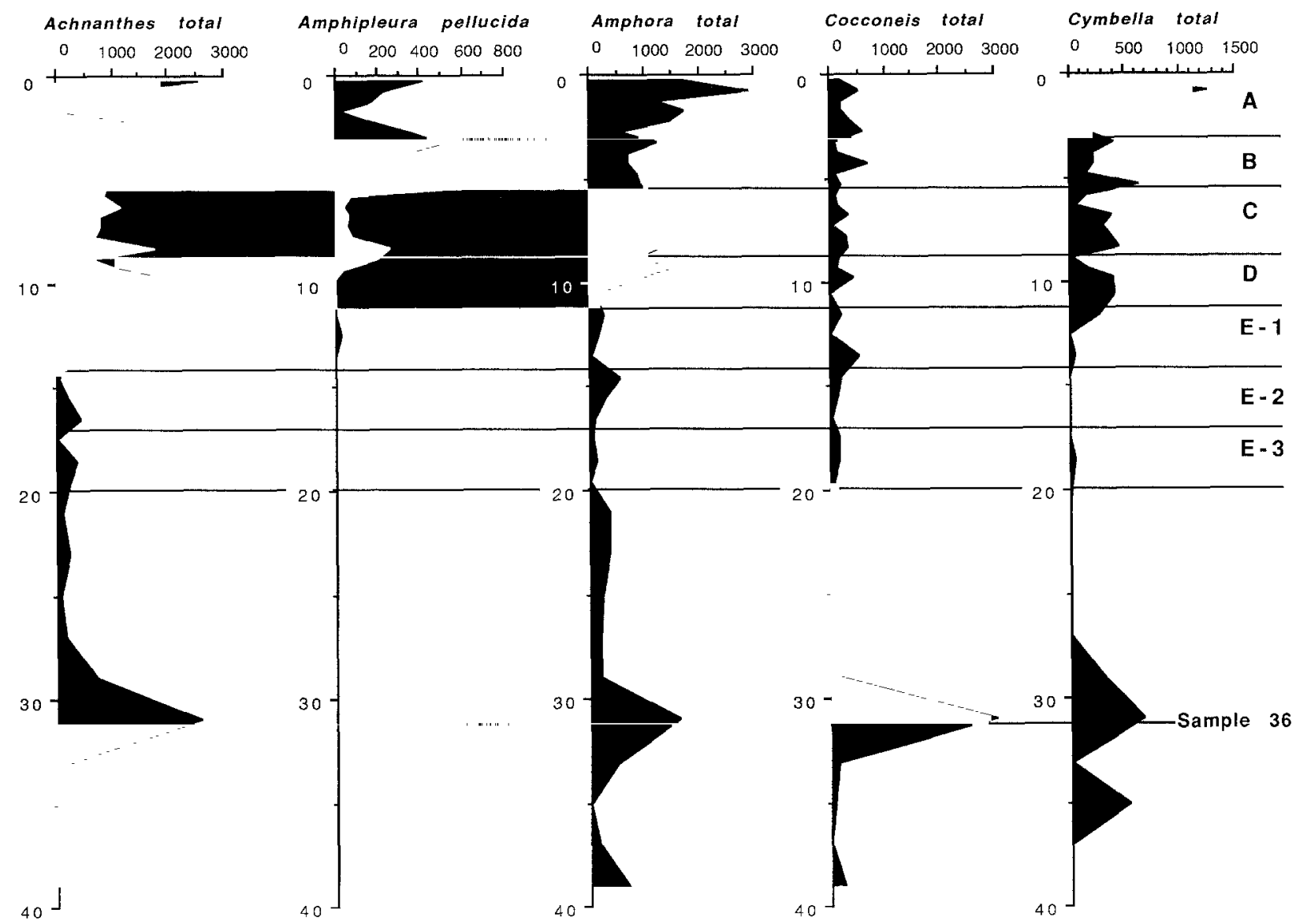

Fig. 13. Abundance (valves $\mathrm{mg}^{-1}$ ) of some primarily benthic taxa relative to depth in core. Zonation indicated by horizontal rules is inferred from cluster analysis.

cernible relationship between diatom abundance in sediments of a given locality and diatom biomass in the immediately overlying waters and concluded that any such relationship is 'erased' by transport. However, considering the unique physical characteristics of Green Bay, the possibility of regionally constrained deposition cannot be excluded.

Particularly in the case of the oligotrophic $C y$ clotella association (Hutchinson, 1967) nutrient supply ratios and their timing may also be important. In the Great Lakes these species are most abundant during the summer (Stoermer \& Ladewski, 1976) and grow primarily in the deep chlorophyll maximum (Fahnstiel \& Glime, 1983). This growth habitat may be most sensitive to modification (Moll \& Stoermer, 1982), particularly the effects of severe summer silica limitation (Shelske \& Stoermer, 1971). In Green Bay continuous high silica loadings from both streams entering the bay and intrusions of hypolimnetic lake Michigan water may prevent exhaustion of silica supplies during the summer while, at the same time, dilution by Lake Michigan water maintains, at least periodically, other factors within the tolerance range of Cyclotella species usually characteristic of oligotrophic habitats.

Although the diatom community in Green Bay may have been, at least, partially buffered from the overriding effects of silica limitation characteristic of post-settement sequences in the lower Great Lakes (Schelske et al., 1983; 1986), most 


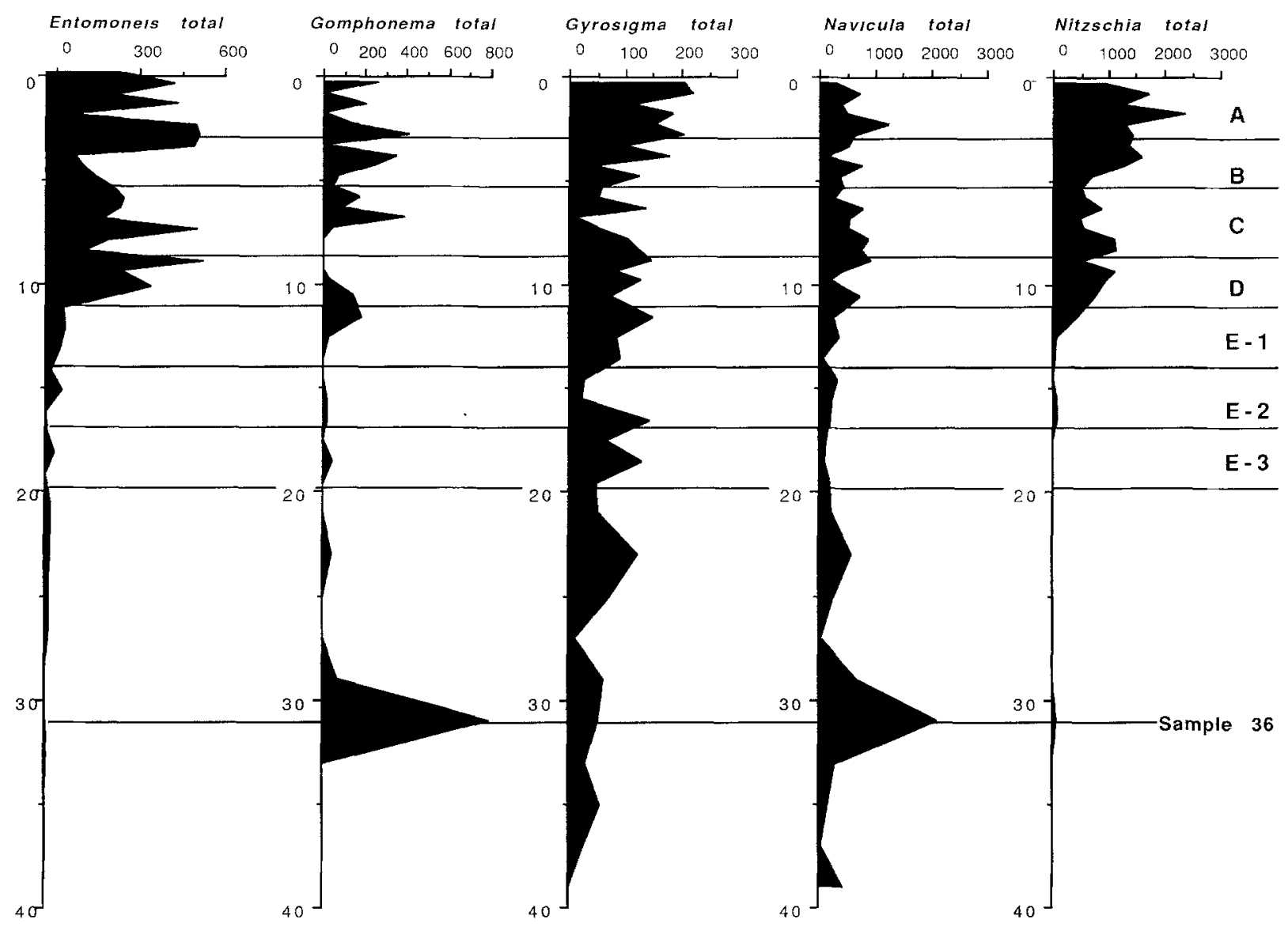

Fig. 14. Abundance (valves $\mathrm{mg}^{-1}$ ) of some primarily benthic taxa relative to depth in core. Zonation indicated by horizontal rules is inferred from cluster analasis.

within-population shifts are consistent with the hypothesis of increased nutrient loadings, at least up to zone B. For instance, Melosira granulata, a species associated with highly eutrophic environments, increases relative to $M$. islandica and $M$. $i$ talica subsp. subartica, species associated with more mesotrophic environments. The same inference applies to increases in the importance of species such as Stephanodiscus binderanus relative to congeners such as $S$. transilvanicus.

Our observations thus indicate that Green Bay, although it has clearly become more eutrophic, in the strict sense of the term implying increased production due to increased nutrient loading, has a substantially different response pattern, particularly in terms of quantitative measures, than other regions of the Great Lakes system. Early settlement (zone E3) produces visible changes in community structure, but only very modest change in microfossil abundance. The slight increase in abundance in the upper part of zone $\mathrm{E} 3$ may reflect extensive wildfires in the region, the most extensive of which occurred in 1871 , but this effect is small compared to the sediment record of settlement in Lake Ontario (Stoermer et al., 1985a). Although further increases in diatom abundance, and concomitant changes in relative species abundance occurred during the late 19th and very early 20th centuries (zone E2), gross changes in the Green Bay system apparently did not begin until approximately the period of World War I (upper part of zone E1). Once initiated, the 
eutrophication process appears to have progressed rapidly, reaching relatively high levels during the WW II era (zone D). Following this, there appears to have been a slight decrease in loading intensity (or perhaps increased dilution) during the 1960 's (zone C) before highest levels were reached in the 1970's (zone B). The effects of nutrient loading reductions may be reflected by apparent decreases in microfossil accumulation (Fig. 2) and relative increases in some more mesotrophic taxa (i.e., Tabellaria, Fig. 5) in the most recent sediments (zone $\mathrm{A}$ ), but this conclusion should be treated with caution. Other taxa associated with eutrophic conditions, particularly species of Stephanodiscus remain at high levels of absolute and relative abundance while Melosira species reach lowest levels in the post-settlement record. Green Bay continues to undergo ecological change, but apparently to a different state than has previously occurred in its recent history.

\section{Acknowledgements}

Contribution No. 537 of the Center for Great Lakes and Aquatic Sciences was supported by Grant No. R-816467 from the U.S. Environmental Protection Agency, Office of Exploratory Research and NSF Grant No. OCE 8614619.

\section{References}

Ahrnsbrak, W. F., 1971. A diffusion model for Green Bay, Lake Michigan. University of Wisconsin Sea Grant Program Technical Report No. 7. University of Wisconsin Sea Grant Program, Madison, WI.

Appleby, P. G., P. J. Nolan, D. W. Gifford, M. J. Godfrey, F. Oldfield, N. J. Anderson \& R. W. Battarbee, 1986. ${ }^{210} \mathrm{~Pb}$ dating by low background counting. Hydrobiologia 143: 21-27.

Bertrand, G., J. Lang \& G. Ross, 1976. The Green Bay watershed, past/present/future. University of Wisconsin Sea Grant Program Technical Report No. 229. University of Wisconsin Sea Grant Program, Madison, WI.

Binford, M. W., 1990. Calculation and uncertainty analysis of ${ }^{210} \mathrm{~Pb}$ dates for PIRLA project sediment cores. J. Paleolim 3: 253-267.

Brunel, J., 1956. Addition du Stephanodiscus Ginderanus a la flore diatomique de l'Amérique du Nord. Nat. Can. 83: 89-95.
Conley, D. J., 1987. Mechanisms controlling silica flux from sediments and implications for the biogeochemical cycling of silica in Lake Michigan. Doctoral Dissertation, University of Michigan, Department of Atmospheric and Oceanic Science. $104 \mathrm{pp}$.

Conley, D. J., C. L. Schelske, B. G. Dempsey, C. D. Campbell \& T. L. Newberry, 1986. Distribution of biogenic silica in the surficial sediments of Lake Michigan. Can. J. Earth Sci 23: 1442-1449.

Fahnenstiel, G. L. \& J. M. Glime, 1983. Subsurface chlorophyll maximum and associated Cyclotella pulse in Lake Superior. Int. Revue ges. Hydrobiol. 68: 605-618.

Heaps, N. S., C. H. Mortimer \& E. J. Fee, 1982. Numerical models and observations of water motion in Green Bay, Lake Michigan. Phil. Trans. r. Soc., London A306: 371398.

Hohn, M. H., 1969. Qualitative and quantitative analyses of plankton diatoms. Bull. Ohio Biol. Surv., N. S. 3: 1-211.

Holland, R. E. 1968. Correlation of Melosira species with trophic conditions in Lake Michigan. Limnol. Oceanogr.13: 555-557.

Holland, R. E. \& L. W. Claflin, 1975. Horizontal distribution of planktonic diatoms in Green Bay, mid-July 1970. Limnol. Oceanogr. 20: 365-378.

Hutchinson, G. E., 1967. A treatise on Limnology. Vol. 2, Introduction to lake biology and the limnoplankton. John Wiley \& Sons, New York.

Lorifice, G. J. \& M. Munawar, 1974. The abundance of diatoms in the southwestern nearshore region of Lake Ontario during the spring thermal bar period. Proc. $17^{\text {th }}$ Conf. Great Lakes Res., p. 619-628. Internal. Assoc. Great Lakes Res.

Miller, G. S. \& J. H. Saylor, 1985. Currents and temperatures in Green Bay, Lake Michigan. J. Great Lakes Res. 11: 97-109.

Moll, R. A. \& E. F. Stoermer, 1982. A hypothesis relating trophic status and subsurface chlorophyll maxima of lakes. Arch. Hydrobiol. 94: 425-440.

Moore, J. R. \& R. P. Meyer, 1969. Progress report on the geological-geophysical survey of Green Bay 1968. University of Wisconsin Sea Grant Technical Report no. 1. University of Wisconsin Sea Grant Program, Madison, WI.

Schelske, C. L. \& E. F. Stoermer, 1971. Eutrophication, sil1ca depletion and predicted changes in algal quality in Lake Michigan. Science 173: 423-424.

Schelske, C. L., E. F. Stoermer, D. J. Conley, J. A. Robbins \& R. M. Glover, 1983. Early eutrophication of the lower Great Lakes: New evidence from biogenic silica in the sediments. Science 222: 320-322.

Schelske, C. L., D. J. Conley, E. F. Stoermer, T. L. Newberry \& C. D. Campbell, 1986. Biogenic silica and phosphorus accumulation in sediments as indices of eutrophication in the Laurentian Great Lakes. Hydrobiologia 143: 79-86.

Schelske, C. L., J. A. Robbins, W. D. Gardner, D. J. Conley \& R. A. Bourbonniere, 1988. Sediment record of biogeochemial responses to anthropogenic perturbations of 
nutrient cycles in Lake Ontario. Can. J. Fish. aquat. Sci. 45: 1291-1303.

Stoermer, E. F., 1968. Nearshore phytoplankton populations in the Grand Haven, Michigan, vicinity during thermal bar conditions. Proc $11^{\text {th }}$ Conf. Great Lakes Res, p. 137-150. Internat. Assoc. Great Lakes Res.

Stoermer, E. F., 1978. Phytoplankton as indicators of water quality in the Laurentian Great Lakes. Trans am. Microsc. Soc. 97: 2-16.

Stoermer, E. F. \& T. B. Ladewski, 1976. Apparent optimal temperatures for the occurrence of some common phytoplankton species in southern Lake Michigan. Univ. Michigan, Great Lakes Res. Div. Pub. 18. 49 pp.

Stoermer, E. F. \& R. J. Stevenson, 1980. Green Bay phytoplankton composition, abundance, and distribution. EPA905/3-79-002. U.S. Environmental Protection Agency, Great Lakes National Program Office, Chicago, IL.

Stoermer, E. F. \& H. Håkansson, 1984. Stephanodiscus parvus: validation of an enigmatic and widely misconstrued taxon. Nova Hedwigia 39: 477-495.

Stoermer, E. F., J. C. Kingston \& L. Sicko--Goad, 1979. The morphology and taxonomic relationships of Stephanodiscus binderanus var. oestrupi (A. Cl.) A. Cl. Nova Hedwigia, Beih. 64: 65-78.

Stoermer,E. F., J. A. Wolin, C. L. Schelske \& D. J. Conley, 1985a. An assessment of ecological changes during the recent history of lake Ontario based on siliceous microfossils preserved in the sediments. J. Phycol, 21: 257-276.

Stoermer, E. F., J. P. Kociolek, C. L. Schelske \& D. J. Conley, 1985b. Siliceous microfossil succession in the recent history of Lake Superior. Proc. Acad. nat. Sci. Philad. 137: 106-118.
Stoermer, E. F., J. A. Wolin, C. L. Schelske \& D.J. Conley, 1985c. Post settlement diatom succession in the Bay of Quinte, Lake Ontario. Can. J. Fish. aquat. Sci. 42: 754767.

Stoermer, E. F., J. P. Kociolek, C. L. Schelske \& D. J. Conley, 1987. Quantitative analysis of siliceous microfossils in the sediments of Lake Erie's central basin. Diatom Res. 2: 113-134.

Stoermer, E. F., G. Emmert \& C. L. Schelske, 1989. Morphological variation of Stephanodiscus niagarae (Bacillariophyta) in a Lake Ontario sediment core. J. Paleolim. 2: 227-236.

Stoermer, E. F., J. A. Wolin, C. L. Schelske \& D. J. Conley, 1990. Siliceous microfossil succession in Lake Michigan. Limnol. Oceanogr. 35: 959-967.

Thayer, V. L., T. C. Johnson \& H. J. Schrader, 1983. Distribution of diatoms in Lake Superior sediments. J. Great Lakes Res. 9: 497-507.

Theriot, E. C. \& E. F. Stoermer, 1984. Principal components analysis of character variation in Stephanodiscus niagarae Ehrenb.: Morphological variation related to lake trophic status. p. 97-111. Proc. VII ${ }^{\text {th }}$ Internat. Diatom Symp. Otto Koeltz, Koenigstein.

Theriot, E. C., H. Håkansson \& E. F. Stoermer, 1988. Morphometric analysis of Stephanodiscus alpinus (Bacillariophyceae) and its morphology as an indicator of lake trophic status. Phycologia 2: 485-493.

Wolin, J. A., E. F. Stoermer, C. L. Schelske \& D. J. Conley, 1988. Siliceous microfossil succession in recent Lake Huron sediments. Arch. Hydrobiol. 114: 175-198. 